\title{
The Influence of Politicians on Television Content in Post-Authoritarian Indonesia
}

\author{
Morissan
}

\begin{abstract}
The downfall of the last authoritarian ruler in May 1998 marked the beginning of the transition to democracy in Indonesia. Before 1998, the autocratic government firmly monitored media content for decades. With the current broadcast liberalization, Indonesian televisions can produce almost any kind of program contents. However, a question arises, who actually controls television content in the era of liberalization? How do political and economic factors influence television workers in shaping content? This empirical research intends to focus on the influence politicians have on television program content in four elections in post-authoritarian Indonesia. The research question is: how do politicians influence television workers in shaping their content? The question needs a qualitative descriptive answer from various sources, including interviews with around 100 television workers in the 10 largest TV stations, participant observations, documents, television reports, and other data sources. Research findings reveal that the relationship between politicians and television intensified ahead and during political campaigns. Most television stations had conducted a relatively fair and nonpartisan coverage of the 2004 and 2009 election, but unfair and partisan in the 1999 and 2014 elections.
\end{abstract}

\section{Keywords:}

politicians; television; elections; post-authoritarian; Indonesia.

\begin{abstract}
Abstrak
Terjatuhnya rezim otoriter pada bulan Mei 1998 menandai dimulainya transisi menuju demokrasi di Indonesia. Sebelum tahun 1998, pemerintah otokratis memonitor konten media selama beberapa dekade. Dengan liberalisasi siaran saat ini, televisi di Indonesia dapat menghasilkan hampir semua jenis isi program. Namun, sebuah pertanyaan muncul, siapa yang sebenarnya mengendalikan konten televisi di era liberalisasi? Bagaimana faktor politik dan ekonomi mempengaruhi pekerja televisi dalam membentuk konten? Penelitian empiris ini bertujuan untuk memusatkan perhatian pada pengaruh politisi terhadap konten program televisi dalam empat pemilihan di Indonesia pasca rezim otoriter. Pertanyaan dari penelitian ini adalah bagaimana politisi mempengaruhi pekerja televisi dalam membentuk isinya? Pertanyaan tersebut membutuhkan jawaban deskriptif kualitatif dari berbagai sumber, termasuk wawancara dengan sekitar 100 pekerja televisi di 10 stasiun TV terbesar, pihak yang terlibat, dokumen, laporan televisi, dan sumber data lainnya. Temuan penelitian mengungkapkan bahwa hubungan antara politisi dan televisi semakin intensif di depan dan selama kampanye politik. Sebagian besar stasiun televisi telah melakukan liputan yang relatif adil dan tidak memihak tentang pemilihan tahun 2004 dan 2009, namun pemberitaan Pemilu 1999 dan 2014 cenderung tidak adil dan memihak.
\end{abstract}

\section{Kata Kunci:}

politisi; televisi; pemilihan; pasca-otoriter; Indonesia.

\footnotetext{
- Faculty of Communication, University of Mercu Buana, Jakarta.

Email: morissan@yahoo.com
} 


\section{Introduction}

The fall of the last authoritarian government in Indonesia in 1998 allowed the rise of freedom followed by the process of transition to democracy in a country with the world's fourth-largest population. After the shift of political power, various reforms in almost all aspects of life developed, particularly the media and press that relished freedom the most.

For decades, the autocratic government firmly monitored the media, and those that dared to ignore or underestimate government control would face fatal consequences. Media permits were frequently revoked, subject to bans, and even closed down without gaining access to open trial. The downfall of President Suharto allows the media to appreciate the new circumstance of being free from the government's strict control.

After the downfall of Suharto regime in 1998, the political and media atmosphere in the country changed altogether from tyrant and tight state control to circumstances characterized by freedom and liberalization, a highly aggressive business sector, and essentially less state intervention (Heryanto \& Adi, 2001: 75).

The Renaissance of Indonesian media was initially stamped by the abolishment of the press permitting procedure (SIUPP) during the presidency of B.J. Habibie in 1999, followed by the abolishment of the information ministry blamed for its tough measures in closing down a number of media during the authoritarian era, and the passing of Press Law No 40/1999 and Broadcast Law No 32/2002 by former president Abdurrahman Wahid. The later advised that an independent body, the Indonesian Broadcasting Commission (KPI), be established. The KPI will function as a partner to the government for managing broadcast media. There was a dramatic increment in the quantity of media, not long after the nullification of the press permitting framework (Gobel \& Escborn, 2005 : 78).
After 1998, once the authoritarian government was ousted and control over media, press permit and content checks were abolished, the media industry grew exponentially. Advertising holds as the very backbone of private TV station's existence. The country's liberalization and democratization process combined with a huge consumer market with increasing amounts of money to spend inspired large companies to increase their investments and promotions as they put the greater part of corporate advertising budget into television (Heryanto, 2002: 327) .

A year after Suharto resigned, the number of print media soared six folds to 1687 although half of these numbers disappeared later due to lack of business viability (Astraatmadja, 2001: 43). In early 2000s, five large new television channels were opened: Global TV, TV 7, Metro TV, Trans TV, and Lativi competing on a national basis with five stations set up earlier during Suharto's era. Some of these stations changed names later due to changes in ownership.

\section{Players in the Television Industry}

Currently, Indonesia becomes the new emerging democratic country and media industry flourish aggressively. Until 2014, there had been five key players in the Indonesian media industry consisting of five large diversified business groups. All 10 national television stations are currently controlled by the five business groups, which also control other types of media. They are: Media Group, Para Group, MNC Group, Bakrie Group, and Emtek Group.

Media Group. The group controls an allnews TV channel, Metro TV, which has over 53 transmission sites all over the country. Based in West Jakarta, Metro TV is the country's first 24-hour news channel. The television channel began to broadcast in the capital in November, 2000. Besides its predominant programming in Indonesian, it is the only TV station to offer Mandarin news. It carried 
programs in Mandarin to cater to its Chinese audience reflecting the easing of restrictions on Chinese language and cultural media imposed during the authoritarian era. Metro broadcasts no sinetron (soap opera) programs, but the station airs entertainment talk show programs. Media group and its television station belong to the businessperson, Surya Paloh, who also owns a national newspaper Media Indonesia daily. Media Group also controls other local newspapers distributed in different parts of Indonesia (Astraatmadja, 2001: 78)

Para Group. The group controls Trans Media Corporation, which manages Trans TV, one of the quickest developing TV stations in Indonesia. The station began broadcasting on the $15^{\text {th }}$ of December 2001, and it has been successful with its entertaining programs in capturing audience interest. Para Group originally focused on three business sectors finance, property and multimedia. Para Group, controlled by businessman Chairul Tanjung, acquired Bank Mega in 1996 (The Jakarta Post, 2011).

Tanjung started his business in 1987 when he and his three companions built up PT Pariarti Shindutama, which manufactured kids' footwear. Tanjung pulled back not long after from the company and built up Para Group, which developed into one of the fastest-growing business conglomerates, and Tanjung became one of Indonesia's wealthiest men in the country. In December 2011, Tanjung changed the name of his business group to $\mathrm{CT}$ Corporation or CT Corp., initial of his name (Bland, 2013: 98).

The initial success prompted Trans Media to acquire the controlling stake of languishing TV 7 owned by an Indonesian giant publisher Kompas Gramedia Group in 2006. The latter is controlled by Jakob Oetama whose reputable daily paper Kompas has been the market leader in Indonesia for decades. However, Kompas Gramedia failed to manage TV 7 successfully prompting the company to sell TV 7 to Trans
Media which then changed the station's name to Trans7.

Chairul Tanjung is close to former President Susilo Bambang Yudhoyono. In 2007, he coordinated several well-known entrepreneurs, and senior government officials to launch the 'Visi Indonesia 2030' (Indonesian Vision 2030) project which mapped out how Indonesia could achieve a 'developed status' by the year 2030 (CTCorp, 2011). Tanjung chaired the project and since then he and his team have become unofficial Presidential advisors.

Bakrie Group. Based in East Jakarta, TVOne is an Indonesian privately owned national television station. Aburizal Bakrie, who controlled private nationwide television station ANTV, expanded his venture in the television industry by buying shares in Lativi, another nationwide TV station grappled with financial difficulties (Wibisono, 2012).

Lativi was established amid the national TV boom in early 2000's. Lativi was initially owned by Abdul Latief, a famous businessman and former minister under Suharto. Latief established the station in 1999, and it commenced broadcasting in 2002. The ownership of the network was changed to Aburizal Bakrie and Erick Thohir by the year 2007 due to debt and poor network management (Wibisono, 2012). The station is currently owned by PT Visi Media Asia, Tbk controlled by Bakrie Group.

TV One was launched on the 14th of February 2008. Aburizal Bakrie and his son Anindya Bakrie continue to dominate shares in Lativi (now TVOne) and ANTV. Anindya and Tohir were appointed as Chief Commissioner and Pesident Director respectively (Wibisono, 2012). Aburizal was once a senior minister in President Yudhoyono's cabinet for the period of 2004-2009. In October 2009, Bakrie was elected chairperson of Golkar, the political party which held power throughout the New Order and which has survived as a key player in the postSuharto political landscape. 
Meanwhile, there has been significant change among the owners of television stations associated with Suharto's family and cronies. The fall of former president Suharto in 1998 had dragged the business empires of his sons and daughters down as well. People like Suharto's second son, Bambang Trihatmojo, and Sudono Salim (also known Liem Sioe Liong, a close Suharto crony) are no longer major owners at their respective televisions.

MNC Group. The group manages media subsidiaries under Bhakti Investama Group, another holding company, which have widely varied business units mainly in the financial service sector. This company group was established by Bambang Hary Tanoesoedibjo, better known as Hary Tanoe, who began gaining popularity in 2002 after he purchased $24.5 \%$ shares in PT. Bimantara Citra Tbk from Bambang Trihatmojo, Suharto's third child. In the same year, Bimantara Citra also took over a US\$ 15 million debt of a television station, TPI, controlled by Suharto's second child, Siti Hardiyanti Rukmana or Tutut. The debt takeover allowed Bimantara to control 75\% of TPI through a subsidiary PT Berkat Karya Bersama (Suprapto, 2013).

Since 2002, Hary Tanoe has held a major share of Bimantara Citra and been its CEO. Bimantara Citra holds 100 percent of PT Media Nusantara Citra (MNC), a holding company which manages media subsidiaries, including nationwide private television channels TPI (now MNC TV), RCTI and Global TV, and the principal permits of three national cable television networks. ${ }^{1}$ MNC also controls major print media and radio stations. In May 2007, Bhakti Investama increased its stake in Bimantara to $52.85 \%$, and at the same time the name of the company was changed to PT. Global Mediacom Tbk, and it became a sub holding of Bhakti Investama in the mass media

1 The three networks are Indovision, Oke TV and Top TV. industry including the broadcasting sector (Cahyafitri, 2014)

Emtek Group. Since 2004, the two brothers, Fofo and Eddy Sariaatmadja, through their own holding company PT Elang Mahkota Teknologi (Emtek Group), purchased shares of PT Surya Citra Media (SCM), which controlled the nationwide private television station SCTV, from Henry Pribadi and Sudwikatmono (Suharto's cousin). However, Suharto's second daughter, Titik Suharto (through her joint share with Sariaatmadjaja's brothers) and Suharto's grandson, Dandy Rukmana, remain members of the SCTV shareholder board (Ida, 2011 : 14). In 2001, Emtek Group also acquired 85\% shares of PT Indosiar Karya Media Tbk, which controls a television station Indosiar, one of the major national television channels in Indonesia.

Apart from the five business groups already mentioned above, seven other media groups also control various media outlets. They are Kompas Gramedia Group, Jawa Pos Group, Mahaka Media, Beritasatu Media Holdings, MRA Media, Femina Group, and Tempo Inti Media. So, a total of 12 business groups currently control nearly all of Indonesia's media outlets, including broadcasting, print media and online media. Although the Indonesian media industry has evolved since the late 1980s, but the 1998 reformasi (reform) became a turning point after which media businesses started to flourish noticeably (Nugroho, et.al 2012).

\section{Media Content}

Censorship regulation, obviously, had existed during post-authoritarian Indonesia, but it is clear that the old practices of government intervention in the media is no longer prevalent. Although the broadcast watchdog, the Indonesian Broadcasting Commission (KPI) with its Public Broadcasting Guidelines and Program Standards (P3SPS), plays a role in controlling content in the era of liberalization, yet it is not the sole controller. When democratization removes government 
intervention in media, and the media enjoy freedom of expression, we have to deal with the following questions: Who ultimately controls the content in the media? Who actually shapes the news and entertainment content on television that we see and hear? For some, these are moot questions in media and communication studies.

With the current liberalization, Indonesian media can produce almost any kind of contents, and such media freedom managed to increase people's awareness regarding the economic and political situation of the country. Nonetheless, a question stands out whether the current media liberalizations could produce responsible and good media practice. The media possess the capability to add to the quality of democracy. Media freedom and independence are great in the event that they support other objectives, including cultural understanding, democracy advancement, prosperity, human development, and so on (Rozumilowicz, 2002: 13).

The general assumption in the development of rebuilding the media is that media should be away from dependency and control. Media reform should advance toward an ideal of independence and freedom. The structure of media is autonomous without interference from governments, owners, politicians, businesses, or dominant social groups (Linz and Stepan, 1996: 76).

In the media literature, issues on factors affecting media content are actually a part of the political economy of media. Political economy as a study started in the eighteenth century, somewhat to clarify, legitimize, and bolster the speeding up of capitalism (Mosco, 1996: 11). According to Mosco (1996: 25), one likewise can consider political economy as the study of the social relations, especially the relations of power that commonly constitute the generation, circulation, and utilization of assets or resources. From this vantage point, the result of communication, such as media content and audiences, are the primary resources.
Some media theorists, including Golding and Murdock (2000 : 35), McQuail (2000: 97), Shoemaker and Reese (1991: 89) and Gerbner et.al (1969: 32) depicted communicators in mass media as working under pressure from internal and external variables such as: proprietors, customers or clients (for example, sponsors), other media (competitors), regulators, viewers, politicians, and others.

\section{Politicians Influences}

The emergence of mass media technologies has enabled us to simultaneously communicate with millions of people creating the possibilities for politicians to communicate with the masses. Not surprisingly, politics became enmeshed with the mass media, thus rendering politicians as key players in producing and circulating political symbolism. The relationship between media and politicians is based on a mutual need. The media need politicians to appear in the media so that they may attract an audience by having access to authority figures. Politicians need to appear in the media to have a platform for their positions.

Unpacking the media's role in the political process is facilitated by examining four themes - the nature of the relationship (institutionalized and informal) between journalists and politicians; how commercial pressures set parameters for journalists; the practices of political journalists; and journalistic belief about their role in the political process. The belief component of liberal journalism can best be understood by examining the notions of the Fourth Estate and watchdog journalism (Louw, 2005, p. 62)

The Fourth Estate and watchdog journalism are two interrelated notions central to the way in which the media/politics relationship has been conceptualized within liberal democracies. This idea grew from the notion that liberal journalists should be adversarial (towards politicians) to be effective watchdogs. Schultz (1998, p.29) notes that 
liberal journalists now adhere to the following self-definition of their role:

1) To be necessarily critical of politicians (adversarial);

2) To champion citizen rights against the abuse of state power;

3) To provide a platform for debate.

Sabato (1991) examined the full range of relationships that can develop between news production personnel and politicians. In this regard, he identifies five type of journalism. Although his notion referred to US journalism, nevertheless these are useful, not just for understanding American journalism, but also for understanding, in general, the sorts of relationships that can emerge between journalists and politicians anywhere.

Partisan Journalist. The first type of journalist-politician relationship is partisan journalism wherein the media support a particular political party, or ideology. This form of media characterized the early liberal oligarchies of Britain and America when middleclass/burgher journalists actively worked to challenge monarchies. Partisan journalists worked collaboratively with those politicians they supported to help promote their causes. This type of journalists flaunt their partisanship and propagandistic role with pride.

Nonpartisan Journalists. Nonpartisan journalists can adopt one of three insider relationships to the liberal political system (Louw, 2005, p.62):

1) The journalist-as-loyal-opposition, or watchdog. This role can take two forms. Firstly, the provider of 'intelligence' (for policy makers). Secondly, the watchdog adversary.

2) The lapdog, where journalists cooperate with politicians making the political system work. It is easy for partisan journalists to slide into becoming lapdog journalist when (successful) revolutionary movements they support become the government;
3) The journalist-as-emotional-provoker. Journalists seek out those aspects of political behavior that provoke emotional responses (e.g. anger, shock or outrage) of the audience because these can be sensationalized and hyped up geared toward attracting mass audiences, rather than an actual concern with politics-as-policy. This type lends itself to politicians working with (or leaking stories to) journalists, in order to undermine their opponents.

The second type of journalist-politician relationship is Fourth Estate Journalism. In this model, journalists are insiders within the liberal political process. This is a part of the policyformulation process as far as they provide the policy-making elites with information, 'intelligence' opinion and a platform for debate. This journalistic genre eschews sensation and titillation, and it can lead to conflict between journalists and politicians since this type of journalists will also publish stories politicians dislike. However, the journalists do not cultivate a necessarily adversarial position. They are also not interested in pursuing political news in the form of political bickering as a means to attract audiences. This genre is associated with 'quality journalism' aimed at elite audiences interested in policy issues (Louw, 2005)

Third, there is muckraking (or 'yellow') journalism, which is commercially driven, strives to build mass audiences through sensationalism. The media attract mass audiences by presenting spectacular, titillating or lurid stories about the rich and famous, including politicians. Stories of conflict, sex and pain are also rampant. Journalists justify such stories by deploying the Fourth Estate principle, which gives them the right to publish whatever they want. This journalistic genre is not driven by political ideals or a concern with policy issues, but by a search for sensational and personal stories. Conflict between journalists and politicians occurs when 'yellow' stories 
impact on political players. This journalistic genre also became associated with corrupt journalistic practices in which politicians pay the media not to publish negative stories.

A fourth type is lapdog journalism. In this category, journalists collaborate with politicians and put aside the watchdog approach. In short, they avoid being adversaries. This collaboration is not necessarily motivated by political partisanship, but is more often driven by a belief that one's society faces 'challenges' serious enough to make adversarial watchdog journalism unhelpful while trying to solve the problems. A sub-variety of lapdog journalism is sunshine journalism, a Third World genre emerging from the New World Information Order/NWIO (Masmoudi, 1979). During the 1970s and 1980s NWIO theorists argued that the problem facing Third World Government was so serious that journalists needed to avoid 'negative' stories which might destabilize them, and instead actively collaborate with their government in producing 'development journalism'. Development journalism deliberately focused on positive news, and stories that promoted modernist development. Much development journalism mutated into propaganda, while sunshine journalism allowed corruption and maladministration to flourish (Masmoudi, 1979).

The fifth, is a variety of watchdog journalism characterized by adversarial watchdogs. This is the belief that journalists, in order to function as effective watchdogs, must be deliberately adversarial towards politicians. Although related to the Fourth Estate approach, adversarial watchdog journalism has less of a policy focus, but more of personality. Since personality and character, are easier to sell to mass audiences, adversarial watchdog journalists tend to focus more on political personalities. The quality of socio-political debate or policy making does not necessarily improve with such watchdogism. Unfortunately, the outcome of this journalist category is mainly controversy and conflict.
The sixth type, junkyard journalism, marries aspects of muckraking to adversarial watchdogism. This genre of attack journalism produces political reporting that is often harsh, aggressive, and intrusive, where feeding frenzies flourish, and gossip reaches print. Every aspect of private life potentially becomes fair games for scrutiny as a new; almost "anything goes" philosophy takes hold (Sabato, 1991: 26). Junkyard journalism is even less helpful than adversarial watchdogism for promoting the exploration, discussion and debate of policy issues. This form of journalism is especially well suited to the needs of commercial media chasing mass audiences because it is a highly sensationalist genre lending itself to voyeuristic stories about conflict, pain and sex associated with the lurid and titillating events in the lives of the rich and famous.

This chapter explores various ideas connected to the notion of the political economy of media with the premise that media content is produced by a range of complex interactions among various political and economic factors. The political economy of the media suggests that politics and economics are not separate substances. Economics and politics are fields whichare best comprehended as being entangled - implying that they are practically inseparable - and that understanding components of this entanglement is urgent to comprehend the way that any society and culture works.

\section{Research Methods}

Most of the research methods used to examine factors affecting television contents are 'media-centric', which means taking, or recording the views from within the media. The reason for this is because only by knowing how the media operate and assess themselves can we understand how society influences the media and vice versa (McQuail, 2000: 123).

This empirical research examines the influence politicians have on television program content in Indonesia during the period of 
1998 - 2014. The research focus is established based on the research questions: How do politicians influence television workers in shaping content? The research question needs a qualitative descriptive answer from various sources, including interview transcripts, notes made conducting field observations, various documents, media and television reports.

Television workers would be the center of attention of this research (subject of study), and answers to the above research question would depend on their opinions, comments, and responses, which have been collected through intensive interviewing. The interviews with 100 television workers and other data sources are expected to reveal a number of cases, which illustrate how advertisers directly or indirectly influence television content.

This research focuses on the ten largest Jakarta-based free-to-air national television stations in Indonesia whose content compositions are not exactly similar. The ten stations are Indosiar, SCTV, RCTI, MNCV TV, Global TV, Metro TV, ANTV, TVOne, Trans TV and Trans 7.

\section{Research Findings}

This research is about the relationship between politicians and television, and it will look at how television contents were influenced by politicians since the advent of broadcasting liberalization in the post-authoritarian era. This study pays most of its attention to the time of the election, either legislative or presidential. This research shows how politicians played their role in utilizing media, and how media in turn used politicians to their advantage during the post authoritarian era.

The following descriptions are highlights of politicians and television relationship at the time when four elections were held during the post-authoritarian era in Indonesia in 1999, 2004, 2009 and 2014.

\section{Politicians Influences in the 1999 Election}

Since the downfall of Indonesia's last authoritarian ruler in May 1998, his successor President B.J. Habibie, held an election on the $7^{\text {th }}$ of June 1999, the first general election after the fall of the Suharto regime. The election was held to select the new member of parliaments with some 48 political parties participating. Under the former constitution, it was the parliament that elected a president. Abdurrahman Wahid, from the National Awakening Party, the fourth largest party in parliament, was elected president while Megawati Sukarnoputri, whose party the Indonesian Democratic PartyStruggle reaped the largest vote, became VicePresident.

The Golkar Party, the former ruling party under Suharto's New Order regime (1966-1998) and the brief presidency of B. J. Habibie (1998-1999) came second in the 1999 election, despite alleged support from several television stations. During the New Order era, Golkar backed previous government of President Suharto, winning greater votes in six consecutive election races. On the other hand, in 1999, Golkar was censured because the party was considered one of the main proponents of the authoritarian regime.

Television coverage during the 1999 election was considered unfair and partial since the reporting only favored the Golkar Party. Throughout these early reform days most television stations continued to support Golkar. Private televisions that were broadcasting in 1999 were considered impartial while state television TVRI acted very obviously as a pro - Golkar channel (Tomsa, 2008: 34).

A research on television coverage during the 1999 election conducted by a non-profit non-governmental organization The Institute for the Studies on Free Flow of Information (ISAI) described its findings on television reportage during the 1999 election with the following remarks (Saptono, 2005: 4). 


\begin{abstract}
"Monitoring showed television coverage gave much advantage to the Golkar party. The activities of Golkar received the largest coverage compared to other parties. Sources from the Golkar party or from those who were sympathetic with it were quoted in much larger proportion compared to those who were critical of it. On contrary to the lingering public opinion, television displayed Golkar party with the image of being tolerant, peaceful, reformist and anti-status quo".
\end{abstract}

The unfair coverage of the 1999 election broadcasted by several television stations was almost unsurprising since they were still under the influence of Suharto's companions, and most of them still maintained direct or indirect links to key politicians in Golkar. Even though the Suharto regime had been ousted in 1998, the uncertainty about the future of Indonesia's transition obviously pushed television owners to remain loyal to Golkar politicians whose party they had backed up for so many years. Two private televisions, ANTV and Indosiar, for example, belonged to Bakrie Group and Salim Group respectively. These two business empires had very close links to the Suharto clan and politicians in Golkar. Another big television, SCTV, was controlled by Suharto's cousin Sudwikatmono who was a major shareholder. TPI was owned by Siti Hardiyanti Indra Rukmana (popularly known as mbak Tutut), Suharto's oldest daughter and former Golkar Chairperson. Last but not least, a company owned by Suharto's son and former Golkar dignitary Bambang Trihatmodjo controlled RCTI, the oldest private television in Indonesia (Tomsa, 2008).

For most television executives, who prospered under the New Order regime, Golkar was still regarded as better suited to defend their interest. For example, former RCTI's deputy chief editor, Desi Anwar, said the news division couldn't be completely autonomous, particularly in the New Order era. "We could not be 100 percent independent. We should consider who owns the station... who owns the shares," Desi said, referring to the relatives of former president Suharto (The Jakarta Post, 1999).

\section{Politicians Influences in the 2004 Election}

Direct election of the President and Vice President became imminent in Indonesia following the amendments of the constitution, and the influence of politicians reached its unprecedented level in 2004 when the country's first-ever direct presidential election was held in the post-authoritarian era. A significant part of the election race occurred in television media, in party messages and advertisements as well as talk shows and entertainment programs (Lindsay, 2005: 43).

During the campaign period, politics and popular culture blended more perfectly than ever before wherein the role of television was central to this process. The blend between popular culture and politics and the appearance of politicians had never been as intense as it was in the period of presidential campaigns when Indonesian people for the first time had a chance to directly elect their new leaders.

In the July 2004 presidential campaign, there were five top politician couples running in the first round of presidential elections: Susilo Bambang Yudhoyono and Jusuf Kalla; Megawati and Hasyim Muzadi; Amien Rais and Siswono Yudo Husodo; Wiranto and Salahuddin Wahid and; Hamzah Haz and Agum Gumelar.

In 2004, there were 24 political parties, which competed with each other for voters' attention, allowing televisions to enjoy more revenues from political advertisements. For example, the presidential candidate Megawati, who was incumbent at that time and her political party, The Indonesian Democratic Party of Struggle (PDI-P), had reportedly spent around 50 billion rupiah (US\$5.5 million) for 
television political advertisements (Sumarkidjo, 2011 : 67). Commenting on political party's expenditure during the 2004 campaigns, former RCTI's Deputy Chief Editor Atmadji Sumarkidjo (personal communication, August, 20, 2013) said:

"Ahead of the presidential election in 2004, television stations were enjoying a lot more advertisements from the competing presidential and vice presidential candidates. Television stations were vying to hold exclusive talk shows with the presidential and vice presidential candidates".

Politicians devised a strategy for launching their campaign programs on television. They didn't rely merely on the 30-second spot advertisements to promote themselves and their political parties; politicians wanted more exposure to televisions by buying special time, known as "blocking time" for their campaigns. In the blocking time contract -much more expensive than regular advertisementtelevision helps politicians, on their request, to create their own program, for example special talk shows or others, or use existing television programs to be dedicated for campaigning of politicians who paid for their appearance in the program.

On the whole, the television coverage during the 2004 election was considered fair and impartial, both for the General and Presidential Elections. Contrary to the 1999 election, politicians' campaign activities of all political parties were covered in most of the televisions. According to the European Union Election Observation Mission (EU EOM) which was invited by the Indonesian Electoral Commission (KPU) to observe the 2004 Election in Indonesia, the tone dedicated to political parties and news distribution throughout the election was fair, reasonable and nonpartisan. Sissener (2004: 22) who wrote a report on behalf of EU EOM said

\begin{abstract}
"For the General Election, the EU EOM assessed that the media coverage of the political parties during the election was fair and impartial. All 24 parties were covered in most of the electronic and print media monitored by the EU EOM. The tone devoted to political parties and distribution of news was fair and neutral. All in all, the contending candidates were seen as being provided with opportunities to share their vision, mission and working programs with the public" (Sissener, 2004: 22)
\end{abstract}

According to EU EOM, only Metro TV performed the worst. The station received a warning from the Broadcasting Commission for presenting too much advertisement in support of Megawati (PDI-P) and Surya Paloh, Golkar's top politician and owner of Metro TV.

Megawati led television coverage because politicians and sympathizers who were capable of buying more advertising time backed her up. Broadcasters at Metro TV showed a reasonable inclination towards President Megawati in their news program. However, this bias considered to have restricted effect on the voters due to the program's lower ratings. With everything considered, all contending candidates were seen as being furnished with equivalent chances to share their vision, mission and working programs (Sissener, 2004: 37).

Meanwhile, the European Parliament (2004) authorized a delegation composed of five members to observe the second round of the presidential election to be held in Indonesia on 20 September 2004. According to the European Parliament, by and large the media assumed a positive role in spreading data about the candidates and all their electoral activities, and by highlighting conceivable campaign infringements. Private televisions, specifically SCTV and RCTI, gave more impartial access to the two competitors than the state channel, especially in news. In the weeks running up to the election races, Metro TV started 
to demonstrate a predisposition for SBY, in contrast to the past round, when it favored Megawati (European Parliament, 2004 : 9-10).

A report by the Institute for the Studies on Free Flow of Information (ISAI) that examined television news coverage during the 2004 election campaign revealed televisions' better performance in three genres: news feature, talk-show, and news bulletin (Saptono, 2005: 437). ISAI said televisions were no longer megaphones or partisans of certain groups or political parties during the 2004 election especially with regard to a feature story, or a television news package containing in-depth journalistic report that covers a selected issue. According to the media research organization, the television feature stories were no longer focusing on one political party or one pair of presidential or vice presidential candidates as the television did during the 1999 election.

Despite being stigmatized as the spoilt rulers' party after over 30 years of relationship with the then ruling New Order government, the Golkar Party hit back to win the 2004 general election. The outcomes of the legislative election indicated that the former president Soeharto's Golkar Party returned to power in the parliament with 128 of 550 seats. The triumph was an inversion of fortune for Golkar, which lost to the Indonesian Democratic Party of Struggle (PDI-P) in the 1999 elections, the first time it had been out of power since 1970 .

\section{Politicians Influences in the 2009 Election}

The 2009 election campaign was characterized by entertainment more than political education and propaganda. Entertainment was the main engine for politicians to grab people's attention. Traditional and modern genres of performance were deployed through various media, from a musical stage performance in kampongs to the fanfare of political entertainment on national televisions. Those performances were held by politicians to gather the masses, to a greater extent than previous elections. Of all the entertainment formats derived from television programs, Indonesian Idol was the one that appealed most to campaigners in the 2009 elections (Heryanto, 2010: 327).

However, despite the extravaganza of political entertainments on the television screen, the election campaigns were considered successful and television displayed their fair role to all contestants. Without precedent for Indonesia's post-authoritarian time, the country had the opportunity to unbiasedly rate the competence and capacities of the presidential candidates in a series of debates held in mid-June 2009. Unlike the 2004 election when televisions vied with each other to hold exclusive interviews with each individual presidential candidate; in the 2009 election, television networks worked together to broadcast the head-to-head presidential debates live throughout the country.

Coordinated by the General Elections Commission (KPU), five private television stations owned by five media moguls worked together to organize the debates featuring all three presidential candidates - Jusuf Kalla of the Golkar Party, Megawati Soekarnoputri of the Indonesian Democratic Party of Struggle (PDI-P), and incumbent President Susilo Bambang Yudhoyono of the Democratic Party (PD). There were a total of five debates, three for presidential candidates and two for vice presidential candidates. Trans TV kicked off the premier televised debate at its studio, which was also broadcasted on four other television stations: Metro TV, RCTI, SCTV, TV One.

Television watchdog, the National Broadcasting Commission (KPI), appreciated the cooperation shown by the five private television networks in promoting the 2009 election especially the successful presidential and vice presidential debates. KPI said the private stations had displayed their commitment 
to work together to broadcast the events in a bid to provide proper political education to the public. KPI (2009) said in a statement:

"KPI also judged that television had become an institution with the biggest role and influence in the socialization process and opinions during the presidential campaigns. The role was implemented in various television programs starting from news programs, talk-shows and others. Television played its enormous rolein the democratization process in Indonesia by transferring conflict from the grass root level to conflicts in media which is considered healthier".

Media analysts considered most television stations had conducted a relatively fair coverage during the 2009 election campaigns for both the legislative and presidential election. They said televisions were able to keep their distance from influences of politicians and the presidential candidates. Atmadji Sumarkidjo said he didn't see televisions, through the reportage they made, blatantly expressing support or sympathy, to a certain candidate during the 2009 election. However, he observed that the incumbent presidential candidate, Susilo Bambang Yudhoyono (SBY), had influence on most television owners. Nevertheless, they managed not to intervene in stations' news policy, allowing people in the news department to do their job quite independently (personal communication, August 20, 2013).

Atmadji Sumarkidjo added that the incumbent candidate had influence on television owners because of his prospect for being reelected in the 2009 election given good performance of his past government. Sumarkidjo said: "Most television owners supported SBY, not through editorial policy, but through any other means like fund contributions or helping campaigns ceremonies" (personal communication, August, 20 2013).
Television workers at two television stations owned by Chairul Tanjung, Trans TV and Trans 7, said the owner supported the incumbent candidate Susilo Bambang Yudhoyono (abbreviated as SBY) and his running mate Boediono before and during the 2009 presidential election. They said Chairul Tandjung showed his support to SBY-Boediono by providing popular artists when the couple addressed an election rally at Senayan stadium. Tandjung also broadcast the rally live through his two television channels. However, apart from this type of support, Tandjung didn't impose his will on journalists at his two televisions. He didn't demand the journalists to also support SBY-Boediono.

Atmadji Sumarkidjo said television coverage on the 2009 election was considered as relatively fair and neutral. The fairness and neutrality of television reportage could be seen from the lack of protests from the losing contestants with regard to media fairness in covering the election campaigns. The losing contestants never accused television stations to have taken side with SBY-Boediono hence allowing them to win the election.

In whole, voters in Indonesia obtained an ample opportunity to access non-biased information thanks to the country's highly dynamic media landscape with almost a dozen national television channels covering the election, reporting on both the government and opposition parties. However, despite the general fairness and neutrality shown by most televisions during the 2009 election, Metro TV was an exception. The station was criticized for broadcasting too much coverage of its owner, Surya Paloh, and the Golkar Party, of which he was still the advisory board chairman. The influence of Surya Paloh and other politicians of the Golkar party on his television channel, Metro TV, was clearly undeniable.

During the 2009 election, Metro TV along with TV One reserved most programming time 
for the elections, branding themselves as the 2009 election channel. Concerns loomed about the independence of the two television stations since both were owned by top members of the Golkar party; TV One owned by the Bakrie family and Metro TV by Surya Paloh. However the two politicans, who were also media owners, were known to be bitter rivals who had vied with each other for the Golkar leadership (Aspinall \& Mietzner, 2010). Elman Saragih, Metro TV's editor-in-chief, said that his will to maintain independence from the influence of politicians and owner-cum-politicians was always alive and well, but in reality, that was not always the case. "We keep trying to reduce the interference [from Surya Paloh] though it is not always that easy," Elman said in his defense (The Jakarta Globe, 2009). He said in reality, there was almost no media organization that was free of special interests. However, he added, Metro TV did maintain impartiality toward other political figures.

\section{Politicians Influences in the 2014 Elections}

In the era of post-authoritarian Indonesia, the 2014 election is likely to be remembered as the fiercest and most confrontational campaign. The reason is because three media moguls who control 10 national television channels in Indonesia joined political parties. They were elected as chairman or senior member of three different political parties. Aburizal Bakrie was elected as Golkar Party's chairman in October 2009; Surya Paloh was elected as chairman of Nasdem Party in January 2013; and, Hary Tanoesoedibjo joined the People's Conscience Party (Hanura) in February 2013. The role of these television owners cum politicians made the 2014 election a fanfare and bewilderment.

Following the legislative election, two names emerged as the strongest candidates for the presidency: Prabowo Subianto, chief of Gerindra Party and Joko Widodo from PDI-P. Prabowo Subianto was a former Lieutenant
General in the Indonesian National Armed Forces. He was the former Army's Special Forces (Kopassus) commander who was fired from his position due to his complicity in the kidnapping of pro-democracy activists in 1998. He became a businessman afterward, and ran for the vice-presidency in the 2009 election accompanying Megawati Sukarnoputri, chairperson of PDI-P, who ran for president.

Joko Widodo, or better known by the abbreviated name Jokowi, is a politician from PDI-P. Jokowi and his running mate Jusuf Kalla managed to garner more parties that support him including National Democrat (NasDem) and the National Awakening Party (PKB) as well as the People's Conscience Party.

Prabowo and his running mate Hatta Radjasa were backed by six parties, including the Golkar Party led by Aburizal Bakrie whose family controlled two television stations. Radjasa was a prominent minister and chairman of the National Mandate Party (PAN). Prabowo was also backed by media tycoon Hary Tanoesoedibjo, the president and CEO of Media Nusantara Citra (MNC) Group, which controls three national television stations and other kind of media outlets.

Following Tanoesoedibjo's pledge to support Prabowo Subianto and Hatta Rajasa in the presidential election, the nation saw the beginning of a fierce political battle involving media magnates who were also politicians. With Tanoesoedibjo's support, Prabowo received a significant campaign boost. Tanoesoedibjo had the biggest share of the free-to-air market with three television stations: RCTI, MNCTV and Global TV. The group also had three pay television networks. Aside from that, Hary controlled a handful of radio stations and Koran Sindo newspaper. Apart from Tanoesoedibjo's media outlets, Prabowo benefitted from his coalition with the Golkar Party, whose chairman Aburizal Bakrie and his family owned PT Visi Media Asia (VIVA), which managed two television 
stations - ANTV and TVOne - as well as online portal Viva news.

Jokowi, on the other hand, received media support from NasDem's Surya Paloh who owns news television channel Metro TV and Media Indonesia daily. However, Paloh's Metro TV only had 3 percent of the country's viewership, compared to 44 percent for the five stations that were pro-Prabowo (Nangoy \& Fabi, 2014). In terms of television stations, Prabowo's camp had much more power than Jokowi's.

In the 2014 election, the use of media by politicians for political campaigns was much more intense compared to the other previous elections and the partisanship was much more obvious as television owners were directly involved. Media moguls cum politicians, with their vibrant soul and powerful financial backup, vied with each other for political power and the media eventually were blamed for running biased coverage of both legislative and especially presidential race. Television campaign coverage was a reflection of the political preferences of station owners. Some television station owners had sided with the Jokowi-Jusuf Kalla pairing, while others chose the Prabowo Subianto-Hatta Rajasa team.

Politicians who controlled several television stations gave excessive coverage and advertising spots to their respective affiliated parties. Television channels belonging to Tanoesudibyo, Paloh, and Bakrie showed special attention to their political parties in the lead up to the legislative and presidential election. For example, TV One and MNC Group had dedicated a higher percentage of presidential election coverage to PrabowoHatta's campaign, while Metro TV had given more airtime to Jokowi-Kalla. TV One devoted a large portion of its news programs to the campaigns of Prabowo. There was no such scope for Jokowi on TV One. On the same day, Paloh's Metro TV broadcasted a live report of Jokowi's speech at different campaign locations, while Bakrie's TVOne refused to air those events. Some stations use various programs, including soap operas, quizzes, reality-shows, and even religious content for campaigns and political ads. $^{2}$

In the Election Day on July 9, 2014 television stations broadcasted the results of quick count surveys of the vote from at least a dozen polling companies which took samples from selected polling stations. Some five pro Prabowo television channels broadcasted live polling results only from polling agencies that predicted he would win the election, while Metro TV only broadcasted results from agencies that afforded victory to Jokowi.

Tensions flared after television stations showed different polling results that led to victory claims from both contenders. Jokowi announced his victory after results of progressing quick counts broadcasted on Metro TV showed his leading position with 52 percent of the vote against Subianto. Other television channels whose owners did not show any blatant political disposition, including SCTV, Indosiar and Trans Corp (Trans TV and Trans 7) also showed Jokowi's leading position in their quick count programs. Later, Prabowo also claimed victory after quick counts from four polling agencies showed him leading with $52 \%$ of the vote.

Television workers interviewed during this research said politicians imposed great influence on their work. They were asked, forced and even intimidated by their superiors to run unbalanced stories during the legislative and presidential campaign. In interviews held for this research, several television workers

\footnotetext{
2 Based on KPI monitoring that lasted from May 19-25, 2014 Prabowo-Hatta coverage at Metro TV was aired only on 110 occasions during the period, lower than Jokowi-Kalla's figure of 187. Conversely, at TV One, the Jokowi-Kalla campaign garnered a mere 79 coverage while there were 153 examples of Prabowo-Hatta campaign coverage. At RCTI, the gap was even greater, with Prabowo-Hatta appearing 30 times compared to seven times for Jokowi-Kalla.
} 
said political affiliated station owners through their superiors demanded reporters to run stories that supported one of the presidential candidates. Television reporters who work at several stations in support of Prabowo and Radjasa said they must support the pairing by running favorable stories about them. Television workers at TV One and ANTV said they were threatened with losing their jobs by the station management if they dared to broadcast content about Jokowi.

In the 2014 election, it was obvious that television stations were predisposed to certain presidential candidate due to political affiliation of the media owners. Tremendous amount of news were diverted by media owners' political preferences even at those television outlets that do not belong to politicians although they didn't show a vulgar partisan attitude. Television worker at SCTV, whose owners were not affiliated to any political parties, said the station was consciously partial and it built information with the objective to affect viewers to vote for a certain candidate that the station's owners supported in the form of continuous news broadcasting of the preferred candidate.

The 2014 election could be seen as one of the most marked event in the history of Indonesian media. During the campaign, it was not easy for television viewers to find objective information, especially political news that could be accounted for. Those who used influence as owners of media networks assumed that media content showing their faces would turn into votes in the election. They hoped that the more content they produced, the more public sympathy and influence they would get. But their expectations were not the equivalent to the reality. Politicians and their political parties that had wide support from the media were not automatically successful in acquiring substantial amount of votes. Prabowo who gained the largest obvious support from the affiliated five national television stations eventually suffered defeat against Jokowi who was backed up by lesser media supports.

\section{Conclusion}

Politicians played an important role in shaping the content of television programs, and the relationship between politicians and the media intensified during political campaigns. The politicians could be elites of political parties who have close relationships with media owners, rich politicians and sympathizers who can afford to buy television blocking time, and ultimately politicians who are also media owners. Of the four elections held in the post-authoritarian era, politicians played a highly significant role in shaping politically related program content especially the news. Most television networks had conducted a relatively fair coverage of the 2004 and 2009 election, but were unfair and partisan in the 1999 and 2014 elections. Indonesian political life faced new development in 2014 as media moguls jumped into the political arena and vied with each other for political power. The result is the fiercest and most confrontational campaign Indonesian people ever remembered due partly to the role of television. Television was blamed for running biased coverage of both legislative and especially presidential race. Television coverage of political campaigns had a tendency to be biased, which most likely is a manifestation of the political inclinations of the station proprietors.

\section{References}

Aspinall, E., \& Mietzner, M. (2010). Problems of Democratisation in Indonesia Elections, Institutions and Society (Eds.). Singapore: ISEAS Publishing.

Astraatmadj. (2001). The Media during and after 'reformasi', Indonesia now and beyond: The Indonesian yearbook 2001. Jakarta: Andrew Tanh Communication

Bland, B. (2013). Chairul Tanjung, CT Corporation: Lessons from Dental Training 
Set The Tone for the INDONESIAN Tycoon's Rise. Financial Times. Retrieved July 28, 2015, from https://www.ft.com/content/abf7814cb7e3-11e2-9f1a-00144feabdc0.

Cahyafitri, R. (2014). Owner does not always deserve to be boss: Hary. The Jakarta Post. Retrieved July 23, 2015, from http://www. thejakartapost.com.

CT Corp. (2011). Visi Indonesia 2030. Retrieved from http://www.ctcorpora.com

European Parliament. (2004). Account of the mission to observe the second round of the presidential elections in Indonesia 20 September 2004. Retrieved July 26, 2015, from http:// www.europarl.europa.eu/intcoop/

Gerbner, G., Larry Gross, Michael Morgan \& Nancy Signorielli. (1969). Living with television: the dynamics of the cultivation process. Retrieved July 23, 2015, from http://web.asc.upenn.edu/gerbner/Asset. aspx?assetID $=1644$

Gobel, R., \& Eschborn, N. (2005). The KAF Democracy Report 2005. Berlin: Konrad Adenauer Foundation.

Golding, P \& Murdock, G. (2000). Culture, Communication and Political Economy in Curran, J., \& Gurevitch, M. (Eds.). Mass media and society ( $3^{\text {rd }}$ ed.). London: Arnold.

Heryanto, A. (2002). The Industrialization of the Media in Democratizing Indonesia. Contemporary Asia, 23(2), 327-55.

. (2010). Entertainment, Domestication

and Dispersal: Street Politic as Popular Culture in Edward Aspinall and Marcus Mietzner (Eds). Problems of Democratisation in Indonesia: Elections, Institutions and Society. Singapore: ISEAS Publishing.

Adi, S. Y. (2001). The Industrialization of The Media in Democratizing Indonesia. In Contemporary Southeast Asia: A Journal of International and Strategic Affairs, 23(2), 327-356.

Ida, R (2011). Reorganisation of Media Power in Post-authoritarian Indonesia: Ownership, Power, and Influence of Local Media
Enterpreneurs. In K.Sen \& D.T. Hill (Eds), Politics and the media in twenty first century: Decade of democracy, Routledge, pp.13-25.

KPI (2009). Monitoring of KPI on Election News on Television (Pemantauan KPI tentang Pemberitaan Pemilu di Televisi). Retrieved July 9, 2015, from http://www.kpi.go.id/index. php/siaran-pers-1/1304-pemantauan-kpitentang-pemberitaan-pemilu-di-televisi

Lindsay, J. (2005). Performing in the 2004 Indonesian elections. Asia Research Institute. Working Paper Series No. 45. Asia Research Institute. National University of Singapore. Retrieved July 18, 2015, from http://www. ari.nus.edu.sg/docs/wps/

Linz, J.J., \& Stepan, A. (1996). Problems of Democratic Transition and Consolidation: Southern Europe, America, and post-communist Europe. USA: The Johns Hopkins University Press.

Louw, P.E. (2005). The Media and Political Process. New York: Sage Publication.

McQuail, D. (2000). Mass communication theory ( $4^{\text {th }}$ ed). New York: Sage Publication.

Mosco, V. (1996). The Political Economy of Communication: Rethinking and Renewal. New York: Sage Publication.

Masmoudi, M. (1979). The New World Information Order. Journal of Communication, 29(2), 172-179.

Nangoy, F \& Fabi, R. (2014). In Indonesia's Presidential Race, Ex-General A Winner in Proxy TV Battle. Retrieved June 27, 2015, from http://www.reuters.com/article

Nugroho, Y., Putri, DA., Laksmi, S. (2012). Mapping the Landscape of The Media Industry in Contemporary Indonesia. Report Series. Engaging Media, Empowering Society: Assessing media Policy and Governance in Indonesia through The Lens of Citizens' Rights. Research collaboration of Centre for Innovation Policy and Governance and HIVOS Regional Office Southeast Asia, funded by Ford Foundation. Jakarta: CIPG and HIVOS. 
Rozumilowicz, B. (2002). Democratic Change: A Theoretical Perspective in Monroe E.P, Rozumilowicz, B \& Stefaan G.V., (Eds.), Media Reform: Democratizing the Media, Democratizing the State. Routledge, p.13.

Sabato, L.J. (1991). Feeding frenzy: How attack journalism has transformed American Politics. New York: Free Press.

Saptono, I. (et.al, 2005). Pemilu di Layar Kaca: Monitoring Berita Pemilu di Media Televisi pada Pemilu 2004. The Institute for the Studies on Free Flow of Information (ISAI). p.437-38

Schultz, J. (1998). Reviving the Fourth Estate: Democracy, Accountability and The Media. Cambridge, UK: Cambridge University Press.

Shoemaker, P.J., \& Reese, S.D., (1991). Mediating the Message: Theories of Influences on Mass Media Content. USA: Longman.

Sissener, T (2004). The Republic of Indonesia: General and Presidential Elections April September. Nordem report 12/2004.

Sumarkidjo, A. (2011). Media dan Pembentukan Opini Publik: Benarkah Televisi Tersandera dan Media Lainnya Masih Independen (Paper Presented at Communication Week 2011). Jakarta: Faculty of Communication, University of Mercu Buana.

Suprapto, H. (2013). Tutut Soeharto, Hary Tanoe, dan Kisruh TPI. Retrieved June 26, 2015, from http://bisnis.news.viva.co.id

The Jakarta Globe. (2009). Metro TV Criticized for Favoring Golkar. Retrieved July 2, 2015, from http://thejakartaglobe.beritasatu.com/

The Jakarta Post. (2011). Chairul Transforms Business Empire, Eyes Expansion. Retrieved July7, 2015, from http://www.thejakartapost. com

The Jakarta Post. (1999). RCTI Editorial Staff Cancels Planned Strike. Retrieved July 17, 2015, from http://www.thejakartapost. com/

Tomsa, D. (2008). Party Politics and Democratization in Indonesia: Golkar in the Post-Suharto Era. United Kingdom: Routledge.

Wibisono, A. (2012). Next tycoons: Anindya Bakrie Assembles a Media Powerhouse in Indonesia. Retrieved June 24, 2015, from http://www. forbes.com 